\title{
Population status of freshwater turtles across a PCB contamination gradient
}

\author{
James P. Gibbs ${ }^{1, *}$, Shahrokh Rouhani ${ }^{2}$, Leyla Shams ${ }^{2}$ \\ ${ }^{1}$ Department of Environmental and Forest Biology, Illick Hall, \\ State University of New York College of Environmental Science and Forestry, Syracuse, NY 13210, USA \\ ${ }^{2}$ NewFields, Atlanta, GA 30309, USA
}

\begin{abstract}
Remarkably few studies on the effects of PCBs on wild turtles have been conducted. We contrasted population-level parameters of 2 species of freshwater turtles, the snapping turtle Chelydra serpentina and the painted turtle Chrysemys picta, across a strong PCB concentration gradient in the upper Hudson River, New York State, USA. Our study employed standardized capture methods that yielded 465 turtles during 1968 trap-nights over 2 yr (2006 and 2007) at 246 trapping sites. Individuals of both turtle species were relatively heavier in a contaminated river segment, but PCB concentration did not otherwise influence relative abundance of turtles, probabilities of habitat occupancy or detection, sex or age ratios, body size, incidence of deformities, external parasite occurrence, or several movement parameters in a manner consistent with adverse impacts to wild turtles. This lack of spatial trend in parameters of wild populations of aquatic turtles across a strong gradient of PCB contamination contrasts with predictions of adverse impacts derived from population modeling, dose-response studies, and tissue residue analyses.
\end{abstract}

KEY WORDS: PCB $\cdot$ Hudson River $\cdot$ Populations $\cdot$ Snapping turtle $\cdot$ Painted turtle

\section{INTRODUCTION}

The upper Hudson River in New York State, USA, was contaminated by the discharge of polychlorinated biphenyls (PCBs) from 2 electric capacitor plants in Fort Edward and Hudson Falls between the 1940s and 1977, after which further seepage and erosion of remnant deposits and contaminated banks continued to release PCBs (US EPA 2000). Fish and wildlife resources of the area are considered to have been adversely affected by the contamination. In the case of aquatic turtles, PCB concentrations in snapping turtle Chelydra serpentina tissues are elevated by 2 orders of magnitude in the contaminated section of the upper Hudson River (averaging ca. 3 ppm in eggs) relative to an uncontaminated segment immediately upriver (averaging ca. 0.02 ppm; Hudson River Natural Resource Trustees 2005). Given an

\footnotetext{
*Corresponding author: jpgibbs@esf.edu
}

$80 \%$ reduction in egg hatching success in snapping turtles predicted to occur at $3.3 \mathrm{ppm}$ (Eisenreich et al. 2009), PCB levels observed in the contaminated segment of the river are considered to pose 'risk' to aquatic turtles (NOAA 2013).

Remarkably few studies on PCB exposure and effects on wild turtles have been conducted (Weir et al. 2010, Salice et al. 2014). Dose-response studies provide an avenue of inquiry and indicate that PCBs can cause adverse impacts to individual turtles (e.g. Eisenreich et al. 2009, Holliday et al. 2009, Holliday \& Holliday 2012, Yu et al. 2012). Such studies can be advantageous for isolating the effect of exposure level to a particular contaminant on the performance of specific traits of individuals; however, implications of such studies of population-level endpoints remain unclear. Wild populations are the unit of biological organization most related to societal values (Selcer

() The authors 2017. Open Access under Creative Commons by Attribution Licence. Use, distribution and reproduction are unrestricted. Authors and original publication must be credited. 
2006). Without an understanding of the demographic implications of reproduction- and survival-related anomalies in individuals reported in laboratorybased, dose-response studies, contaminant-mediated population-level effects cannot be assumed (Akçakaya et al. 2008). Population modeling offers an alternative for exploring contaminant impacts under more field-relevant contexts. For example, Salice et al. (2014) concluded through deterministic population projection models that persistent contamination by PCBs in the upper Hudson River and the reduction it apparently causes in juvenile snapping turtle survival (Eisenreich et al. 2009) could translate into negative effects on the abundance of adult snapping turtles.

Field-based assessments of turtle population status across contamination gradients, although rarely undertaken, provide yet another and more direct approach for assessing population-level impacts as long as habitat covariates are controlled for. As is often the case with evaluations of contamination impacts on riverine biota, the geography of the PCBimpacted segment of the upper Hudson River is a complex array of aquatic and terrestrial habitats juxtaposed with urban-to-rural gradients of land use (Vispo \& Knab-Vispo 2011). This mix of ecosystem heterogeneity and anthropogenic disturbances confronts turtles with complex mixtures of contaminants from agricultural and residential as well as industrial sources in the larger context of severe loss and fragmentation of habitats due to agriculture and urban development, with major potential impacts on turtle populations (Rizkalla \& Swihart 2006).

In this study, we used a field-based assessment of turtle population status in relation to $\mathrm{PCB}$ exposure while controlling for habitat covariates to assess Salice et al.'s (2014) prediction that prolonged PCB exposure would reduce aquatic turtle population abundance in the upper Hudson River. To do so, we sampled aquatic turtle populations and habitat parameters up- and downriver of the source of PCB contamination in the Hudson River and within the sampling frame employed by the Hudson River Natural Resource Trustees in its assessments of contaminant loads in aquatic turtles and other river biota (NOAA 2013). These river segments varied strongly and consistently in terms of PCB concentrations in turtle eggs. Snapping turtle eggs in the uncontaminated, upriver 'reference' segment had an average PCB concentration $187 \pm 182(\mathrm{SD}) \mathrm{ppb}$, whereas the PCBcontaminated segment spanned 3 regions with substantially elevated PCB concentrations: Region 1 at $9840 \pm 10400$ (SD) ppb, Region 2 at $6330 \pm 7710$ ppb, and Region 3 at $4290 \pm 1690$ ppb (regions designated by and estimates obtained from the Hudson River Natural Resource Trustees 2005).

Our study focused on 2 species of aquatic turtles, snapping turtles and painted turtles Chrysemys picta, because these were the best represented elements of the reptile community in the upper Hudson River and are frequent targets of toxicological studies (Bergeron et al. 1994, Bell et al. 2006), including in the Hudson River (Hudson River Natural Resource Trustees 2005, Kelly et al. 2008, Eisenreich et al. 2009, Salice et al. 2014). In addition to examining whether PCB exposure was associated with reduced turtle abundance, we assessed whether sex ratios were female-biased due to the feminizing effects of PCBs on developing embryos (Bergeron et al. 1994), whether individual fitness was reduced as reflected in lower body condition, and whether physical deformities were more prevalent (Bell et al. 2006). These studies were complemented by a study of snapping turtle movement ecology to infer the extent to which aquatic turtles in the river segments studied were demographically distinct and hence represented statistically independent population segments.

\section{MATERIALS AND METHODS}

This study's sampling frame was shoreline habitats along a ca. $100 \mathrm{~km}$ segment of the upper Hudson River between Waterford, New York, northwards and upriver to the confluence of Sacandaga and Hudson Rivers at Lake Luzerne. Within this area, exclusions were made for areas unsafe to navigate by small boat: a $3 \mathrm{~km}$ long swift water section between Hudson Falls and Fort Edward and short segments $100 \mathrm{~m}$ up- and downriver of all dams and locks. Within the sampling frame, 246 sampling sites $\geq 100 \mathrm{~m}$ apart were established at random locations along the river's shoreline. Inter-trap distances were chosen to achieve sample independence later validated via spatial autocorrelation analysis of turtle relative abundance implemented via the 'ncf' package in R (Bjornstad 2016, see 'Results'). Turtles were trapped at each sampling site during each of 2 years of study: between 28 May and 13 August 2006 and between 26 May and 4 August 2007 (pre-dating remediation efforts including dredging within the river initiated in 2009). Trapping dates coincided with the peak of annual activity in these species (Gibbs et al. 2007) and were scheduled in an alternating manner among river segments to avoid conflating any seasonal bias in turtle capture probability with river position. 
Turtle populations were sampled using the most widely used method for monitoring and assessing freshwater turtle populations: baited hoop nets (Mali et al. 2014). Baited hoop nets have well-known biases (e.g. Ream \& Ream 1966) but provide valid inference about differences in population status if deployed consistently among populations being contrasted. Each net comprised 3 hoops ( $3 \mathrm{ft}[\sim 90 \mathrm{~cm}]$ in diameter) covered with 1 inch $(2.54 \mathrm{~cm})$ mesh size netting and anchored to the river substrate with wooden poles. Traps were baited at deployment with the contents of a $100 \mathrm{~g}$ can of sardines packed in vegetable oil. All traps were checked daily and removed 5 d later, yielding 4 'trap nights' per sampling site per year. For all turtles captured, straight-line carapace length was measured with tree calipers $( \pm 1 \mathrm{~mm})$ from the tip of the cervical scute posterior to the tip of the most distal marginal scute. Mass was measured with a Pesola ${ }^{\circledR}$ digital hanging scale. All individuals were inspected for visible ectoparasites (leeches) and external deformities following criteria outlined by Bell et al. (2006). All turtles captured were marked by notching the right supracaudal marginal scute; only initial captures were included in analyses.

Habitat conditions were characterized at each turtle trapping site. Water quality variables measured at each trap's entrance whenever it was checked included turbidity (measured by Secchi disk depth, to the nearest $\mathrm{cm}$ ), temperature, and specific conductance (with an Oakton Waterproof pH 300 Meter). River bank slope nearest to the trap location was visually estimated. Substrate composition was estimated in July 2007 at all trapping sites as the fraction of points dominated by rocks or gravel versus muck, sand, clay, or vegetation sampled at $2 \mathrm{~m}$ intervals along a line parallel to the shoreline and intersecting with the trap and extending from $10 \mathrm{~m}$ upriver to $10 \mathrm{~m}$ downriver of each trapping site for 10 points in total. Availability of potential basking platforms was estimated from counts of logs, rocks, or other objects unattached to the shore, protruding above the water surface, able to support a basking turtle, and occurring within $10 \mathrm{~m}$ of a trap. River morphology associated with each trapping site was characterized in terms of river width, mean river depth, and river depth variability (the coefficient of variation of river depth measurements). To do so, a perpendicular transect was established that extended between the trapping site and the opposite shoreline. River depth was measured along this transect at $10 \mathrm{~m}$ intervals. Position was determined with a Bushnell Yardage Pro Sport 450 laser rangefinder aimed at a reflecting object (a $1 \times 1 \mathrm{~m}$ piece of sheet metal) placed at the transect origin on the river bank. River depth at each sampling point was measured with a HawkEye Handheld Digital Depth Sounder. Last, length of shoreline and extent of land cover types (aggregate vegetated wetland, agriculture, developed land, and forest as a fraction of the non-open water area) within a 100 m radius circular area centered on each trapping site were estimated from the New York State Area Hydrography dataset (1:24 000) and the National Land Cover Dataset 2001 (Homer et al. 2007, resolution $30 \mathrm{~m}$ ), respectively, both obtained from the New York State GIS Clearinghouse.

A complementary study of snapping turtle movement ecology was conducted to examine whether the samples of aquatic turtles in the 2 population segments contrasted were indeed independent (if intermixing of turtles was high, our samples would not reflect distinct populations with consistently different PCB exposure histories) and because movement is an important behavioral attribute potentially affected by PCB exposure (cf. Deem et al. 2009). Radio-transmitters were attached to 22 individuals captured in baited hoop nets in June and July 2008: 11 turtles (3 females and 8 males) in the reference river segment and 11 turtles (2 females and 9 males) in the contaminated river segment. Sex ratios of animals marked reflected the typical male-bias in hoop net samples of aquatic turtles (Ream \& Ream 1966) and were matched to the extent possible upstream versus downstream within the total sample of 22 turtles the largest sample we could track with a field crew of 2 full-time technicians available. Turtles were fitted with $30 \mathrm{~g}$ transmitters (model AI-2F, Holohil Systems) with a battery life of 18 mo following the recommendations of Boarman et al. (1998) and re-located with a Yagi directional antenna in conjunction with an R1000 telemetry receiver (Communications Specialists); each turtle's geographical coordinates $( \pm 2 \mathrm{~m})$ were then determined using a Garmin eTrex handheld 12-channel global positioning system device. Individuals were located once every 1 to $2 \mathrm{wk}$ from the time of capture until mid-September in 2008 and then again between late May and mid-September 2009 (that is, across 2 peak activity seasons and 2 nesting seasons), after which we recaptured all turtles, removed their radios, and then released the animals. Contrasts of turtle population parameters were predicated on a null expectation of independence of any given population parameter's estimate relative to river segment (contaminated versus reference).

Generalized linear mixed modeling (GLMM) (McCulloch et al. 2008) was conducted using IBM SPSS Statistics 23 (www.ibm.com/analytics/us/en/ 
technology/spss/) to contrast relative abundance between river segments while controlling for environmental variables and year. The dependent variable in GLMM was the reported turtle counts at each trap in a given year, treated as a site-specific repeated measurement. Independent variables of turtle sex/age and trap ID were treated as site-specific attributes, whereas other variables such as temperature, river width, river depth, and PCB concentrations were considered as site-specific covariates. GLMM assumes a specific distribution for the dependent variable (in our study Poisson and negative binomial distributions of turtle capture success) and uses maximum likelihood estimation procedures to predict the model parameters and their associated significance.

Turtle survey data were also analyzed using siteoccupancy models (MacKenzie et al. 2002) to differentiate between the probabilities of site occupancy $(\psi)$, colonization $(\gamma)$ and extinction $(\varepsilon)$, and species detection (p) by incorporating site and sampling covariates using Program PRESENCE version 11.5 (MacKenzie 2012). Site and sampling covariates included region (upriver reference, region 1, 2, or 3), median PCB concentration, and average PCB concentration (derived from Hudson River Natural Resource Trustees 2005). The Simple Multi-Season Model (MacKenzie 2012) was used for the analysis. Model outputs included season- and site-specific occupancy and colonization probabilities, as well as site- and sampling-specific detection probabilities, with seasons referenced to 2006 (4 trap nights per trap site) and 2007 (also 4 trap nights per trap site). Prior to the analysis, categorical variables were replaced by their equivalent indicator variables, i.e. 1 when the category matched and 0 otherwise. We assessed a large subset of possible models that directly addressed the study's a priori hypothesis, that is, site occupancy $(\psi)$ and detection probability (p) were affected by PCB exposure as indexed by region (upriver reference, and Regions 1, 2, or 3), or median PCB concentration and average PCB concentration. Akaike's information criterion (AIC) of each model was computed and ranked; models with $\triangle \mathrm{AIC}$ (the difference between a particular model AIC and the minimum AIC) smaller than 2 were considered equivalent (Burnham \& Anderson 2002).

Population parameters based on frequenciestraps capturing turtles, females in sample, adults, individuals above median turtle length in the entire river system (an index of population size structure), deformities, and hosting leeches - were contrasted between river segments using the $G$ statistic for the log-likelihood ratio goodness of fit test with Williams' correction for continuity (Sokal \& Rohlf 1995). Thresholds used for size at maturity (classification as 'adult') were $\geq 20 \mathrm{~cm}$ carapace length for snapping turtles and $\geq 11 \mathrm{~cm}$ carapace length for painted turtles (Ernst et al. 1994).

Body condition (relative mass per unit length) for a given turtle was assessed using a nonparametric generalized additive mixed modeling approach (Hastie \& Tibshirani 1990), which enabled controlling for the nonlinear relationship between body mass and body size while partitioning out the effects of the categorical covariates sex/age and river position (using the $\mathrm{R}$ package gamm4, Wood 2009).

Evaluation of the influence of snapping turtle sex, body size (carapace length), and river segment on snapping turtle movement parameters was undertaken through an ANCOVA (Field 2009) using IBM SPSS Statistics 23 in which turtle sex and river segment were treated as fixed factors, with body size and turtle movement parameters as the covariate and dependent variable, respectively.

Mean values of turtle habitat parameters were contrasted between the contaminated and reference river segments with a Student's 2-tailed $t$-test for independent samples.

All tests with probabilities $\alpha \leq 0.05$ were interpreted as 'significant.'

\section{RESULTS}

Riverine habitats associated with turtle trapping sites in the contaminated river segment differed significantly $(p<0.05)$ from those in the reference segment mostly in terms of characteristics of uplands surrounding the river: a $400 \%$ increase in extent of agriculture nearby, a $167 \%$ increase in amount of development nearby, and a $32 \%$ decrease in extent of forest (Table 1), along with a $113 \%$ increase in water conductivity, a $40 \%$ decrease in substrate rockiness, a $38 \%$ decrease in turbidity, a $29 \%$ decrease in bank slope, a $23 \%$ decrease in river depth, a $10 \%$ decrease in river width, a $9 \%$ increase in river depth variation, and a $4 \%$ increase in water temperature (Table 1).

Total sampling effort for turtles equaled 1968 trapnights over $2 \mathrm{yr}$ at the 246 trapping sites. Pooled across sites and years, trapping 'success' averaged 11.3 snapping turtles and 4.2 painted turtles per 100 trap nights. In 2006, we captured a total of 225 turtles (Table 2): mostly snapping turtles (82\% of total captures) and painted turtles (17\%) as well as 3 map tur- 
Table 1. Habitat attributes at 246 turtle trapping sites within the upper Hudson River contrasted with Student's $t$-tests between a PCB-uncontaminated reference segment (upriver of Glens Falls, New York) and a contaminated segment (downriver of Fort Edward, New York). Data are mean \pm SD

\begin{tabular}{|c|c|c|c|c|}
\hline Variable & $\begin{array}{c}\text { Reference } \\
(\mathrm{n}=103)\end{array}$ & $\begin{array}{c}\text { Contaminated } \\
(\mathrm{n}=143)\end{array}$ & $t$ & $\mathrm{p}$ \\
\hline Turbidity (m) & $2.75 \pm 0.67$ & $1.70 \pm 0.66$ & 12.3 & 0.001 \\
\hline Temperature $\left(\mathrm{C}^{\circ}\right)$ & $23.40 \pm 1.88$ & $24.39 \pm 2.38$ & 3.4 & 0.001 \\
\hline 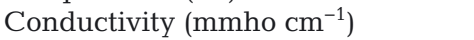 & $79.33 \pm 24.87$ & $169.41 \pm 50.19$ & 15.9 & 0.001 \\
\hline Bank slope (\%) & $0.59 \pm 0.30$ & $0.42 \pm 0.20$ & 5 & 0.001 \\
\hline Substrate (\% rock or gravel) & $0.55 \pm 0.61$ & $0.33 \pm 0.56$ & 2.8 & 0.004 \\
\hline Basking platforms (within $10 \mathrm{~m}$ ) & $1.96 \pm 3.01$ & $2.66 \pm 3.43$ & 1.6 & 0.097 \\
\hline River depth $(\mathrm{m})$ & $3.72 \pm 2.10$ & $2.88 \pm 1.22$ & 3.6 & 0.001 \\
\hline River width (m) & $206.45 \pm 85.65$ & $185.33 \pm 68.28$ & 2.1 & 0.032 \\
\hline River depth variation (CV) & $0.53 \pm 0.13$ & $0.58 \pm 0.12$ & 2.5 & 0.012 \\
\hline Wetland (within $100 \mathrm{~m})^{\mathrm{a}}$ & $0.05 \pm 0.13$ & $0.03 \pm 0.10$ & 1.0 & 0.324 \\
\hline Development (within $100 \mathrm{~m})^{\mathrm{a}}$ & $0.03 \pm 0.08$ & $0.08 \pm 0.15$ & 3.2 & 0.002 \\
\hline Agriculture (within $100 \mathrm{~m})^{\mathrm{a}}$ & $0.02 \pm 0.06$ & $0.1 \pm 0.13$ & 6.3 & 0.001 \\
\hline Forest (within $100 \mathrm{~m})^{\mathrm{a}}$ & $0.38 \pm 0.20$ & $0.26 \pm 0.16$ & 5.1 & 0.001 \\
\hline Length shoreline within 100 m (m) & $239.36 \pm 96.12$ & $233.08 \pm 85.53$ & 0.5 & 0.589 \\
\hline${ }^{\mathrm{a}}$ Extent as fraction of total area & & & & \\
\hline
\end{tabular}

mean PCB concentration estimated in a particular river segment did not affect relative abundance of either turtle species (Table 3B).

Occupancy models (Table 4), all with high estimated goodness of fit, indicated that, for snapping turtles, river association (upriver or downriver), mean PCB concentration, or median PCB concentration did not consistently affect probabilities of habitat occupancy or detection, with model-averaged estimates of probabilities of habitat occupancy (0.4-0.6) and detection (0.15-0.20) among top $(\triangle \mathrm{AIC}<2$ units) models comparable among river segments (Table 5). Similarly, for

tles Graptemys geographica, 2 stinkpots Sternotherus odoratus, and a single wood turtle Glyptemys insculpta. In 2007, the same 246 sites were resampled, yielding a total of 240 turtles, mostly snapping turtles (62\%) and painted turtles (32\%), as well as 3 map turtles and 10 stinkpots (Table 2). Only 13 snapping turtles and 2 painted turtles were recaptured during the study; all analyses reported are based on initial captures only.

Relative abundance of aquatic turtles was uncorrelated at the $100 \mathrm{~m}$ inter-trap distance implemented, suggesting that trapping sites represented independent samples: mean Moran's $I$ for total captures over both years was $0.020(-0.243$ to $0.262,95 \% \mathrm{CI})$ for snapping turtles and $0.020(-0.218$ to $0.227,95 \% \mathrm{CI}$ ) for painted turtles.

When related to time (year) and environmental variables at capture sites via a GLMM, traps disproportionately captured male snapping turtles and did so in segments of the river that were wider, shallower, and surrounded by more open water (Table 3A). Relative abundance of painted turtles also was higher where the river was wider and where more extensive wetland, basking platforms, and turbid waters occurred (Table 3A). Notably, river position (upriver or reference versus downriver or contaminated) had no influence on capture success of either snapping or painted turtles. When the same analysis was conducted including mean PCB concentration in turtle eggs as determined for the 4 river segments designated by the Hudson River Natural Resource Trustees (2005), outcomes were similar; most notably, painted turtles the single top-ranked model (Table 4), which had a very high estimated goodness of fit, did not include region, mean PCB concentration, or median PCB concentration as a determinant of probability of habitat occupancy (0.20-0.25, Table 5), although it did include region as a co-variate of detection probability (ranging from 0.00-0.40), with painted turtles showing among the lowest and high-

Table 2. Number of individuals of aquatic turtle species captured in traps in the upper Hudson River during 2006 and 2007. Values reflect initial turtle captures; all re-captures were excluded from analyses

\begin{tabular}{|lcrrr|}
\hline \multirow{2}{*}{ Species } & River segment & \multicolumn{3}{c}{ Year } \\
\cline { 3 - 5 } & & 2006 & 2007 & Both \\
\hline \multirow{2}{*}{ Snapping turtle } & Contaminated & 116 & 107 & 223 \\
& Reference & 64 & 43 & 107 \\
& Entire & 180 & 150 & 330 \\
Painted turtle & Contaminated & 25 & 58 & 83 \\
& Reference & 14 & 19 & 33 \\
Wood turtle & Entire & 39 & 77 & 116 \\
& Contaminated & 0 & 0 & 0 \\
Map turtle & Reference & 1 & 0 & 1 \\
& Entire & 1 & 0 & 1 \\
Stinkpot & Contaminated & 3 & 3 & 6 \\
& Reference & 0 & 0 & 0 \\
Total & Entire & 3 & 3 & 6 \\
& Contaminated & 2 & 10 & 12 \\
& Reference & 0 & 0 & 0 \\
& Entire & 2 & 10 & 12 \\
& & 225 & 240 & 465 \\
\hline
\end{tabular}


est detection probabilities in the river segments with elevated PCB contaminations (Table 5).

All other turtle population parameters estimated were independent of river position in both 2006 and in 2007 and for both snapping turtles and painted turtles (Table 6) with 3 exceptions: a higher proportion of female snapping turtles was captured in the reference segment in 2007, a higher proportion of large male snapping turtles was captured in the contaminated segment in 2006 and in 2006/2007 combined, and a higher proportion of female painted turtles was captured in the reference river segment in both 2007 and in 2006/2007 combined. Notably, no patterns in physical deformities, of a moderate or minor degree, in individual turtles were evident in contrasts of aquatic turtle populations in contaminated versus reference river segments (Table 6), nor were major deformities observed in either river segment.

Generalized additive models explained much of the variation in turtle mass (91\% in snapping turtles, $84 \%$ in painted turtles); after controlling for carapace length, male painted turtles were lighter than females and individuals of both species were heavier in the contaminated than in the reference river segment (Table 7).

Mean cumulative distance traveled by 22 snapping turtles across successive relocations over the $1.5 \mathrm{yr}$ tracking period was $3.00 \pm 1.92 \mathrm{~km}\left(\mathrm{SD}_{i} \min .=0.92\right.$, max. $=9.68)$ for a daily rate of mean $=0.04 \pm 0.02 \mathrm{~km}$ $\mathrm{d}^{-1}$ (min. $=0.01$ max. $=0.12$ ). Snapping turtles remained close to initial capture sites over 2 seasons: the average maximum distance among any relocation of any given turtle during the 2 seasons was just $0.93 \pm 0.62 \mathrm{~km}(\min =0.31, \max =3.37)$. The distance moved between the first and last capture as a fraction of cumulative distance moved across all relocations was just $0.18 \pm 0.14 \mathrm{~km}(\min .=0.03 \max .=0.67)$. Notably, snapping turtles, which were all initially captured in the river's main channel, subsequently remained mostly within the main channel itself: an average of $0.77 \pm 0.34(\min .=0.1 \max .=1.0$ ) of total relocations of each individual were within the river channel. When turtles left the river, the average maximum distance from the river's shore was $0.12 \pm$ $0.19 \mathrm{~km}$ (min. $=0.10 \max .=0.70)$. ANCOVA indicated independence across the sample of 22 turtles tracked in terms of cumulative distance moved and daily movement rate in relation to turtle sex, size (carapace length), and location in the contaminated versus reference river segment (Table 8). Although our intent was not to measure snapping turtle survival rates, it is notable that no marked turtle died over 2 seasons of monitoring in either river segment.
Table 3. Generalized linear mixed models explaining relative abundance (capture success) of snapping turtles and painted turtles at 246 trapping sites along a $100 \mathrm{~km}$ extent of the upper Hudson River (see 'Methods' for variable descriptions). Analyses were structured using 2 approaches: (A) upriver (uncontaminated) / downriver (contaminated) contrast, and (B) average $\mathrm{PCB}$ concentration contrast among 4 river segments (regions) as designated by the Hudson River Natural Resource Trustees (2005) with strongly varying average PCB in turtle eggs: Reference $=$ average $\mathrm{PCB}$ concentration of $187 \mathrm{ppb}(\mathrm{n}=103$ trapping sites), Region $1=9843 \mathrm{ppb}(\mathrm{n}=41$ trapping sites), Region $2=$ $4986 \mathrm{ppb}(\mathrm{n}=64$ trapping sites), and Region $3=4287 \mathrm{ppb}(\mathrm{n}=38$ trapping sites). The upriver (uncontaminated) segment included the Reference segment as designated by the Hudson River Natural Resource Trustees (2005) whereas the downriver (contaminated) segment included Regions 1, 2, and 3. Bold values indicate significant coefficients $(\mathrm{p} \leq 0.05)$. Data are mean \pm SD

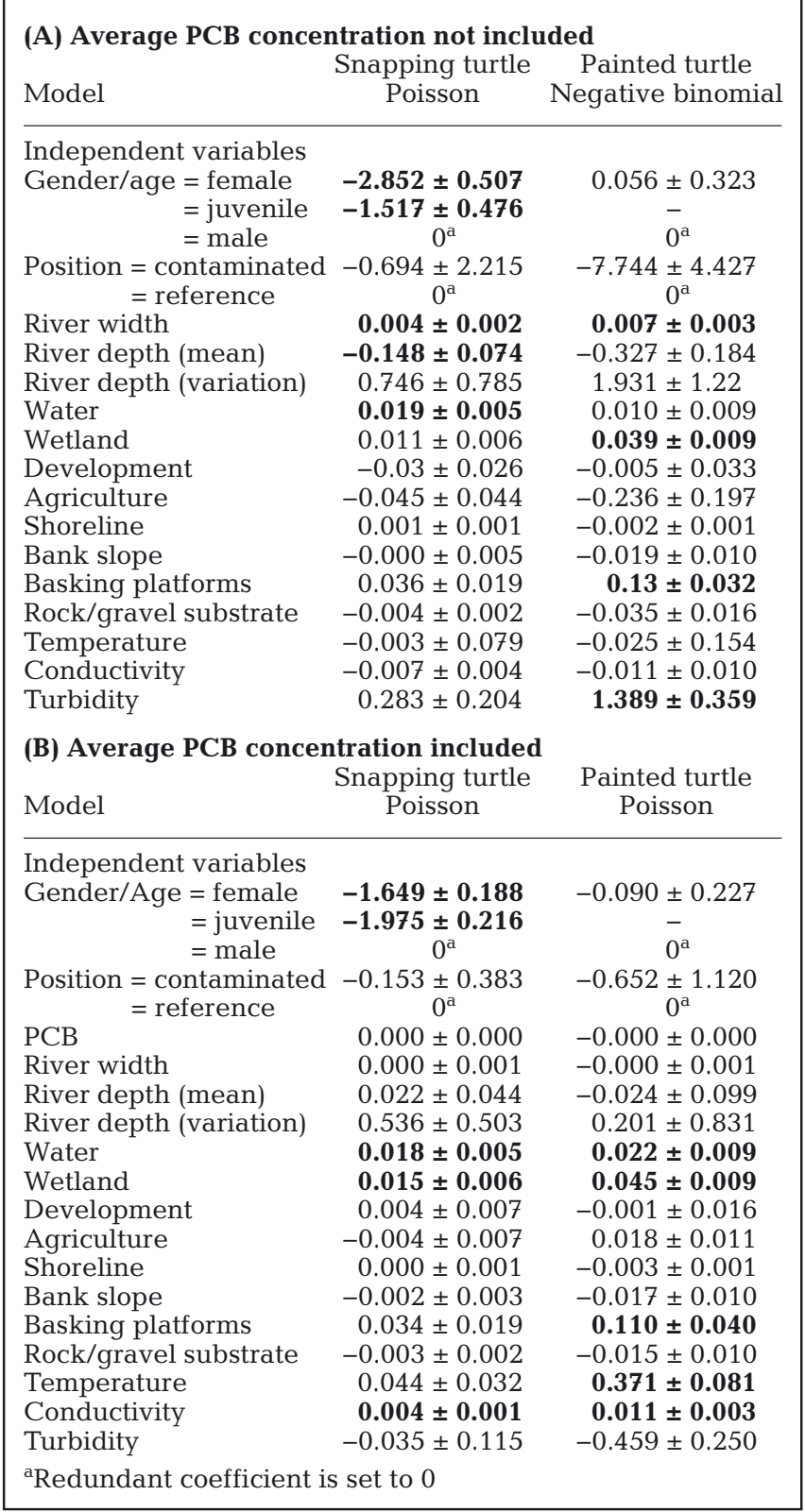


Table 4. Occupancy models for estimating site occupancy $(\psi)$, detection $(p)$, colonization $(\gamma)$, and local extinction $(\varepsilon)$ for 2 freshwater turtle species (snapping turtle and painted turtle) associated with 246 trapping sites in the upper Hudson River each sampled over $4 \mathrm{~d}$ in both 2006 and 2007 . Weight is a measure of support for each model; $k$ denotes number of parameters and -2LL denotes -2 log likelihood. Site and sampling covariates include: Region (upstream reference, and Regions 1, 2, or 3) and average and median PCB concentration in turtle eggs in each river segment (derived from Hudson River Natural Resource Trustees 2005)

\begin{tabular}{|c|c|c|c|c|c|c|c|c|c|c|}
\hline No. & Model & AIC & $\Delta \mathrm{AIC}$ & $\begin{array}{c}\text { AIC } \\
\text { weight }\end{array}$ & Model & $k$ & $\begin{array}{c}-2 \mathrm{LL} \\
\text { likelihood }\end{array}$ & $\begin{array}{c}\text { Chi- } \\
\text { squared }\end{array}$ & $\mathrm{p}$ & Model $\mathrm{R}^{2}$ \\
\hline \multicolumn{11}{|c|}{ Snapping turtle } \\
\hline 1 & $\psi(),. \gamma(),. \mathrm{p}()$. & 1407.4 & 0 & 0.215 & 1 & 5 & 1397.4 & 2.008 & 1.000 & 0.999 \\
\hline 2 & $\psi($ Region $), \gamma(),. \mathrm{p}()$. & 1407.7 & 0.26 & 0.189 & 0.878 & 8 & 1391.7 & 3.166 & 1.000 & 0.961 \\
\hline 3 & $\psi($ Region $), \gamma($ Region $), p()$. & 1408.8 & 1.35 & 0.109 & 0.509 & 11 & 1386.8 & 3.213 & 1.000 & 0.963 \\
\hline 4 & $\psi(),. \mathrm{r}(),. \mathrm{p}($ AveragePCB $)$ & 1409.1 & 1.69 & 0.092 & 0.430 & 6 & 1397.1 & 2.076 & 1.000 & 0.998 \\
\hline 5 & $\psi($ AveragePCB $), \gamma(),. \mathrm{p}()$. & 1409.1 & 1.7 & 0.092 & 0.427 & 6 & 1397.1 & 2.110 & 1.000 & 0.995 \\
\hline 6 & $\psi(),. \gamma(),. \mathrm{p}($ MedianPCB $)$ & 1409.3 & 1.9 & 0.083 & 0.387 & 6 & 1397.3 & 2.037 & 1.000 & 0.998 \\
\hline 7 & $\psi($ MedianPCB $), \gamma(),. \mathrm{p}()$. & 1409.4 & 2 & 0.079 & 0.368 & 6 & 1397.4 & 2.009 & 1.000 & 0.999 \\
\hline 8 & $\psi(),. \gamma(),. \mathrm{p}($ Region $)$ & 1410.6 & 3.23 & 0.043 & 0.199 & 8 & 1394.6 & 2.308 & 1.000 & 0.993 \\
\hline 9 & $\psi($ AveragePCB $), \gamma(),. \mathrm{p}($ AveragePCB $)$ & 1411.1 & 3.68 & 0.034 & 0.159 & 7 & 1397.1 & 2.080 & 1.000 & 0.997 \\
\hline 10 & $\psi($ MedianPCB), $\Upsilon \gamma \gamma(),. \mathrm{p}($ Region $)$ & 1412.8 & 5.36 & 0.015 & 0.069 & 9 & 1394.8 & 2.314 & 1.000 & 0.993 \\
\hline 11 & $\psi($ AveragePCB $), \gamma(),. \mathrm{p}($ Region $)$ & 1412.8 & 5.37 & 0.015 & 0.068 & 9 & 1394.8 & 2.506 & 1.000 & 0.984 \\
\hline 12 & $\psi($ Region $), \gamma(),. \mathrm{p}($ Region $)$ & 1412.8 & 5.38 & 0.015 & 0.068 & 11 & 1390.8 & 3.102 & 1.000 & 0.963 \\
\hline 13 & $\psi($ MedianPCB $), \gamma(),. \mathrm{p}($ MedianPCB $)$ & 1412.9 & 5.54 & 0.014 & 0.063 & 7 & 1398.9 & 2.128 & 1.000 & 0.997 \\
\hline 14 & $\psi($ Region), $\gamma($ Region), p(Region) & 1414.2 & 6.82 & 0.007 & 0.033 & 14 & 1386.2 & 3.308 & 1.000 & 0.960 \\
\hline \multicolumn{11}{|c|}{ Painted turtle } \\
\hline 1 & $\psi(),. \gamma(),. \varepsilon(),. \mathrm{p}($ Region $)$ & 518.74 & 0 & 0.961 & 1.000 & 7 & 504.7 & 3.756 & 1.000 & 1.000 \\
\hline 2 & $\psi($ Region $), \gamma(),. \mathrm{p}()$. & 526.72 & 7.921 & 0.018 & 0.0191 & 6 & 514.7 & 4.702 & 1.000 & 0.954 \\
\hline 3 & $\psi($ Region $), \gamma(),. \varepsilon(),. \mathrm{p}()$. & 526.73 & 7.935 & 0.018 & 0.0189 & 6 & 514.7 & 4.831 & 1.000 & 0.954 \\
\hline 4 & $\psi($ AveragePCB $), \gamma(),. \mathrm{p}()$. & 532.53 & 13.686 & 0.001 & 0.0011 & 5 & 522.5 & 6.356 & 1.000 & 0.970 \\
\hline 5 & $\psi($ MedianPCB $), \gamma(),. \varepsilon(),. \mathrm{p}()$. & 534.54 & 15.688 & 0.000 & 0.0004 & 5 & 524.5 & 32.444 & 1.000 & 0.903 \\
\hline 6 & $\psi(),. \gamma($ MedianPCB $), \mathrm{p}()$. & 535.02 & 16.221 & 0.000 & 0.0003 & 6 & 523.0 & 2.689 & 1.000 & 0.997 \\
\hline 7 & $\psi(),. \gamma($ AveragePCB $), p()$. & 535.09 & 16.293 & 0.000 & 0.0003 & 6 & 523.1 & 2.602 & 1.000 & 0.998 \\
\hline 8 & $\psi(),. \gamma($ Region $), \varepsilon($ Region $), \mathrm{p}()$. & 535.19 & 16.589 & 0.000 & 0.0002 & 9 & 517.2 & 2.721 & 1.000 & 0.989 \\
\hline 9 & $\psi(),. \gamma($ Region $), \mathrm{p}()$. & 536.50 & 17.760 & 0.000 & 0.0001 & 7 & 522.5 & 2.446 & 1.000 & 0.997 \\
\hline 10 & $\psi(),. \gamma($ MedianPCB $), \varepsilon($ MedianPCB $), p()$. & 536.91 & 18.175 & 0.000 & 0.0001 & 7 & 522.9 & 2.813 & 1.000 & 0.996 \\
\hline 11 & $\psi(),. \gamma($ AveragePCB $), \varepsilon($ AveragePCB $), p()$. & 537.26 & 18.518 & 0.000 & 0.0001 & 7 & 523.3 & 2.659 & 1.000 & 0.997 \\
\hline 12 & $\psi($ AveragePCB $), \gamma(),. \varepsilon(),. \mathrm{p}()$. & 537.69 & 18.840 & 0.000 & 0.0001 & 5 & 527.7 & 42.970 & 1.000 & 0.916 \\
\hline 13 & $\psi(),. \gamma(),. \varepsilon(),. \mathrm{p}()$. & 537.98 & 19.135 & 0.000 & 0.0001 & 5 & 528.0 & 2.163 & 1.000 & 0.945 \\
\hline 14 & $\psi(),. \gamma(),. \mathrm{p}()$. & 537.98 & 19.135 & 0.000 & 0.0001 & 5 & 528.0 & 3.756 & 1.000 & 1.000 \\
\hline 15 & $\psi(),. \gamma(),. \varepsilon(),. \mathrm{p}($ AveragePCB) & 538.82 & 20.025 & 0.000 & 0.0001 & 6 & 526.8 & 1.440 & 1.000 & 0.994 \\
\hline 16 & $\psi(),. \gamma(),. \mathrm{p}($ AveragePCB $)$ & 538.82 & 20.025 & 0.000 & 0.0001 & 6 & 526.8 & 1.440 & 1.000 & 0.994 \\
\hline 17 & $\psi(),. \gamma(),. \varepsilon(),. \mathrm{p}($ MedianPCB) & 539.11 & 20.317 & 0.000 & 0.0001 & 6 & 527.1 & 6.196 & 1.000 & 0.995 \\
\hline 18 & $\psi($ Region$), \gamma($ Region $), \varepsilon($ Region $), p()$. & 543.14 & 24.470 & 0.000 & 0.0001 & 8 & 527.1 & 19.875 & 1.000 & 0.918 \\
\hline
\end{tabular}

\section{DISCUSSION}

This study took advantage of the upper Hudson River as a site where PCB concentrations were among the highest reported in the US (Baker et al. 2006) to examine whether PCB exposure could cause adverse, population-level impacts to wild turtles in a manner both substantive and additive to other anthropogenic impacts that typically confront reptiles in the environment (Gardner et al. 2007). Our population assessment of aquatic turtles was robust insofar as it involved a large number of independent study sites $(\mathrm{n}=246)$ sampled over $2 \mathrm{yr}$ (for a total of almost 2000 trap-nights) via a long-established, standardized, and widely-employed capture technique (baited hoop nets). We assumed that detection prob- ability (cf. MacKenzie et al. 2002) of both species of turtles did not vary between river segments, which occupancy modeling bore out for snapping turtles and apparently for painted turtles given the lack of any clear relationship between detection probabilities and PCB exposure (lowest in the most contaminated river segment, highest in the second-most contaminated segment, and intermediate in the uncontaminated and third-most contaminated segments). Movement analyses of snapping turtles confirmed that the 2 primary population samples contrasted between contaminated and reference river segments were likely independent given the observed sedentariness of snapping turtles. In sum, the study did not reveal consistent variation in population-level parameters in wild populations of either 
Table 5. Parameter estimates $( \pm \mathrm{SE})$ from occupancy models for estimating site occupancy $(\psi)$, detection $(\mathrm{p})$, colonization $(\gamma)$, local extinction $(\varepsilon)$ for 2 freshwater turtle species (snapping turtle and painted turtle) associated with 246 trapping sites in the upper Hudson River each sampled over $4 \mathrm{~d}$ in both 2006 and 2007

\begin{tabular}{|cccc|}
\hline Location & Parameter & $\begin{array}{c}\text { Snapping } \\
\text { turtle }\end{array}$ & $\begin{array}{c}\text { Painted } \\
\text { turtle }\end{array}$ \\
\hline Reference & $\psi_{2006}$ & $0.452 \pm 0.055$ & $0.233 \pm 0.074$ \\
& $\psi_{2007}$ & $0.543 \pm 0.085$ & 0.207 \\
& $\mathrm{p}_{2006}$ & $0.200 \pm 0.024$ & $0.095 \pm 0.038$ \\
& $\mathrm{p}_{2007}$ & $0.146 \pm 0.021$ & $0.167 \pm 0.052$ \\
& $\gamma$ & $0.260 \pm 0.104$ & $0.085 \pm 0.063$ \\
Region 1 & $\varepsilon$ & 0.064 & $0.392 \pm 0.183$ \\
& $\psi_{2006}$ & $0.438 \pm 0.069$ & $0.233 \pm 0.074$ \\
& $\psi_{2007}$ & $0.528 \pm 0.093$ & 0.207 \\
& $\mathrm{p}_{2006}$ & $0.204 \pm 0.030$ & $0 \pm 0$ \\
& $\mathrm{p}_{2007}$ & $0.148 \pm 0.026$ & $0 \pm 0$ \\
& $\gamma$ & $0.313 \pm 0.115$ & $0.085 \pm 0.063$ \\
Region 2 & $\varepsilon$ & 0.142 & $0.392 \pm 0.183$ \\
& $\psi_{2006}$ & $0.519 \pm 0.068$ & $0.233 \pm 0.074$ \\
& $\psi_{2007}$ & $0.606 \pm 0.083$ & 0.207 \\
& $\mathrm{p}_{2006}$ & $0.202 \pm 0.026$ & $0.253 \pm 0.093$ \\
& $\mathrm{p}_{2007}$ & $0.147 \pm 0.023$ & $0.395 \pm 0.078$ \\
& $\gamma$ & $0.250 \pm 0.124$ & $0.085 \pm 0.063$ \\
& $\varepsilon$ & 0.025 & $0.392 \pm 0.183$ \\
Region 3 & $\psi_{2006}$ & $0.468 \pm 0.063$ & $0.233 \pm 0.074$ \\
& $\psi_{2007}$ & $0.559 \pm 0.093$ & 0.207 \\
& $\mathrm{p}_{2006}$ & $0.202 \pm 0.026$ & $0.101 \pm 0.054$ \\
& $\mathrm{p}_{2007}$ & $0.147 \pm 0.023$ & $0.177 \pm 0.078$ \\
& $\gamma$ & $0.252 \pm 0.114$ & $0.085 \pm 0.063$ \\
& $\varepsilon$ & 0.046 & $0.392 \pm 0.183$ \\
\hline
\end{tabular}

snapping turtles or painted turtles associated with PCB exposure, which presumably has been prolonged given the average age of reproducing female snapping turtles of 34 to $40 \mathrm{yr}$ in northern populations (Galbraith et al. 1988, Congdon et al. 1994) and that reduction of PCB levels in the river did not occur substantially until after our study was concluded, i.e. in 2009 with the initiation of site remediation (dredging) activities.

Radio-telemetry studies suggested that snapping turtles moved very little, ranging on average $<1 \mathrm{~km}$ over 2 activity seasons from their initial capture point. This degree of sedentariness is consistent with other reports that ranging behavior in snapping turtles is minimal (Kiviat 1980, Obbard \& Brooks 1981, Galbraith et al. 1987). Despite the occurrence of hydrologically connected and unconnected wetland along the river's length, snapping turtles primarily remained in the river itself ( $75 \%$ of all re-locations). Snapping turtle population status in the upper Hudson River is therefore likely heavily influenced by habitat conditions within the river itself, including PCB exposure levels, as opposed to those of off-river wetlands (Bowne et al. 2006). Although we did not include painted turtles in our movement comparison, painted turtles appear to be even less mobile than snapping turtles in this region (Patrick \& Gibbs 2010), although other studies suggest that painted turtles occupying rivers elsewhere in North America can make extended movements $(>20 \mathrm{~km})$ over a single active season (MacCulloch \& Secoy 1983).

Although river segment or PCB exposure did not influence capture success for either species examined, we did identify habitat variables affecting variation in turtle abundance. More snapping turtles were trapped at sites with more open-water habitats and shallower and wider segments of the river. Painted turtles showed a similar response except that they were more abundant at sites with increased availability of palustrine wetlands nearby, more basking platforms, and higher water turbidity. Both snapping and painted turtles are known to use a variety of permanent or semi-permanent lentic and lotic waters (e.g. ponds, lakes, marshes, swamps, ditches, and occasionally salt marshes) within their ranges, including significantly polluted and eutrophic habitats (snapping turtles: Galbraith et al. 1988, Brown et al. 1994; painted turtles: DeCatanzaro \& ChowFraser 2010). For painted turtles, the association with greater numbers of basking platforms likely reflects their need to bask regularly, which is critical for increasing body temperature above ambient water temperatures in order to increase metabolic rates and rate of energy assimilation to ensure fat accumulation for reproduction and overwintering, which is particularly important at the northern edge of these species' ranges, which include the upper Hudson River (Gibbs et al. 2007).

Our study primarily implemented an upriver/ downriver experimental design as do many assessments of contaminant effects on wildlife, including PCB impacts on the biota of the upper Hudson River (NOAA 2013). While this study design can be considered an example of 'pseudo-replication' (sensu Hurlbert 1984), landscape-scale ecological studies such as this one do not generally permit classical experimentation because the treatment cannot be replicated (Hargrove \& Pickering 1992). Nevertheless, within our study area we explicitly considered environmental covariates that also might drive variation in our response variables between the 2 treatment areas, which enabled development of a correlational understanding between turtle population response and environmental characteristics including PCB exposure.

Habitat differences that we observed between upriver and downriver sites (Table 1) emphasize the 
Table 6. Contrasts of population parameters for snapping turtles and painted turtles in a PCB-contaminated versus reference segment of the upper Hudson River in 2006 and 2007 and in both years combined

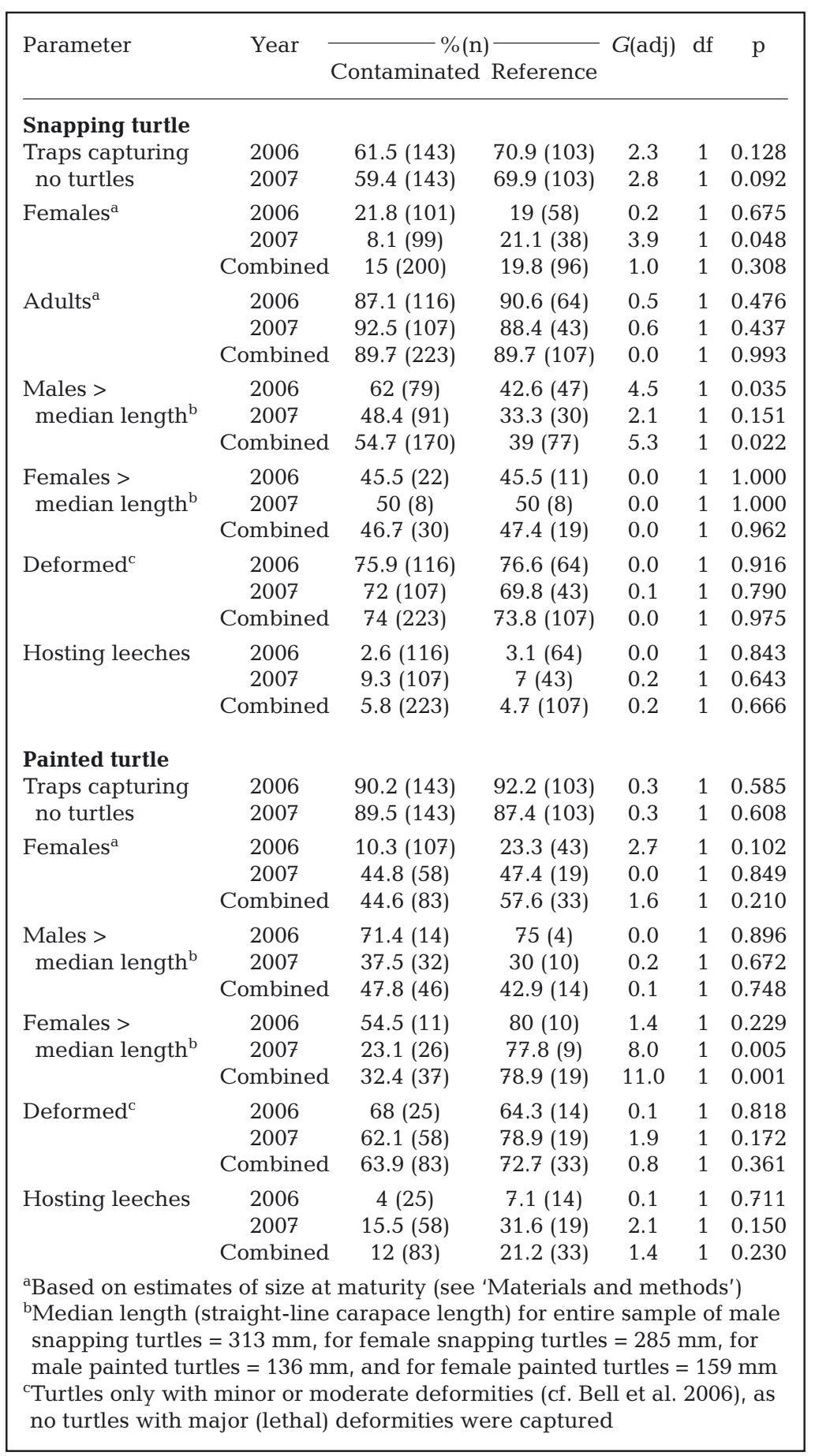

agriculture and urban development on upland landscapes nearby trapping sites, elevated water conductivity (higher ionic concentration), less rocky substrates at trapping sites, clearer waters, reduced extent of forest on adjacent river banks, lower bank slopes, shallower river depths, narrower river width, more consistent river depth, and slightly warmer water temperatures (Table 1). Some of these differences may reflect increased nutrients and human-generated organic waste in water bodies in more developed landscapes, which may benefit freshwater turtles in terms of enhanced food sources and aquatic vegetation (Knight \& Gibbons 1968, Souza \& Abe 2000). Without simultaneously controlling for environmental conditions when contrasting populations with different histories of PCB exposure levels at the spatial scale of river segments, as we did with GLMMs of relative abundance (Table 3), ecological influences on turtle abundance could have been conflated with contaminant impacts.

Environmental factors also affected traits of individual turtles. After controlling for carapace length, individuals of both turtle species were heavier in the contaminated than the reference river segment, and a higher proportion of large male snapping turtles was found in the contaminated than in the reference segment in 2006 and in 2006/2007 combined (Table 6). Greater relative mass is generally considered to reflect greater individual fitness in reptiles (Wikelski \& Romero 2003) insofar as relatively heavier turtles have more reserves to allocate for growth, reproduction, and overwintering. The lower reaches of the river with their slower, warmer waters and greater nutrient levels (as indexed by higher overall water conductivity, Table 1) may represent more productive habitats in terms of food availability and opportunity for mass gain given the affinity (and presumably higher fitness) of both snapping and painted turtles for warmer waters and more eutrophic habitats (Galbraith et al. 1988, DeCatanzaro \& Chow-Fraser 2010). Notably, any spatial pattern in physical deformities, of moderate, minor,

or major degree was lacking, an outcome consistent need to control for environmental conditions inherent to river segments when using upriver/downriver experimental designs, which most research on PCB impacts on Hudson River biota do not (NOAA 2013). More specifically, the downriver segment had more 
Table 7. Summary of generalized additive models fitted to snapping turtles $(\mathrm{n}=330)$ and painted turtles $(\mathrm{n}=116)$ captured in the upper Hudson River in 2006 and 2007, to explore relationships between body mass and age/sex and river segment (PCBcontaminated versus reference) while controlling for individual turtle length

\begin{tabular}{|c|c|c|c|c|c|c|c|}
\hline \multirow[t]{2}{*}{ Parameter } & \multicolumn{4}{|c|}{ Parametric coefficients } & \multicolumn{3}{|c|}{$\begin{array}{c}\text { Nonlinear effects } \\
\text { (nonparametric) }\end{array}$} \\
\hline & Estimate & SE & $t$ & $\mathrm{p}$ & $\mathrm{df}$ & $F$ & $\mathrm{p}$ \\
\hline \multicolumn{8}{|l|}{ Snapping turtle (deviance explained $=91.4 \%$ ) } \\
\hline Constant & 8.036 & 0.205 & 39.074 & $<0.001$ & & & \\
\hline Sex/age (female vs. juvenile) & -0.605 & 0.470 & -1.287 & 0.199 & & & \\
\hline Sex/age (female vs. male) & -0.350 & 0.213 & -1.638 & 0.102 & & & \\
\hline River segment (contaminated vs. reference) & -0.693 & 0.154 & -4.482 & $<0.001$ & & & \\
\hline Carapace length & & & & & 6.487 & 340.6 & $<0.001$ \\
\hline \multicolumn{8}{|l|}{ Painted turtle (deviance explained $=84.5 \%$ ) } \\
\hline Constant & 0.410 & 0.010 & 42.253 & $<0.001$ & & & \\
\hline Sex (female vs. male) & -0.034 & 0.015 & -2.220 & 0.0284 & & & \\
\hline River segment (contaminated vs. reference) & -0.043 & 0.011 & -4.068 & $<0.001$ & & & \\
\hline Carapace length & & & & & 2.814 & 68.56 & $<0.001$ \\
\hline
\end{tabular}

Table 8. ANCOVA of snapping turtle movement parameters in relation to river segment (reference versus contaminated) and individual turtle sex and carapace length for 22 turtles tracked over 2 activity seasons in the upper Hudson River

\begin{tabular}{|c|c|c|c|c|c|c|}
\hline Dependent variable & Source & Type III SS & $\mathrm{df}$ & MS & $F$ & $\mathrm{p}$ \\
\hline \multirow{8}{*}{$\begin{array}{l}\text { Average daily } \\
\text { movement }\end{array}$} & Corrected model & 0.001 & 3 & 0.000 & 0.383 & 0.767 \\
\hline & Intercept & 0.002 & 1 & 0.002 & 3.803 & 0.067 \\
\hline & $\begin{array}{l}\text { River segment (contaminated } \\
\text { versus reference) }\end{array}$ & 0.000 & 1 & 0.000 & 0.591 & 0.452 \\
\hline & Sex & 0.000 & 1 & 0.000 & 0.107 & 0.747 \\
\hline & Carapace length (cm) & 0.000 & 1 & 0.000 & 0.690 & 0.417 \\
\hline & Error & 0.011 & 18 & 0.001 & & \\
\hline & Total & 0.046 & 22 & & & \\
\hline & Corrected total & 0.012 & 21 & & & \\
\hline \multirow{8}{*}{$\begin{array}{l}\text { Cumulative distance } \\
\text { moved }\end{array}$} & Corrected model & 4.465 & 3 & 1.488 & 0.367 & 0.778 \\
\hline & Intercept & 4.113 & 1 & 4.113 & 1.014 & 0.327 \\
\hline & $\begin{array}{l}\text { River segment (contaminated } \\
\text { versus reference) }\end{array}$ & 0.116 & 1 & 0.116 & 0.029 & 0.867 \\
\hline & Sex & 4.400 & 1 & 4.400 & 1.085 & 0.311 \\
\hline & Carapace length $(\mathrm{cm})$ & 0.038 & 1 & 0.038 & 0.009 & 0.924 \\
\hline & Error & 72.992 & 18 & 4.055 & & \\
\hline & Total & 275.345 & 22 & & & \\
\hline & Corrected total & 77.457 & 21 & & & \\
\hline
\end{tabular}

with other reports of a lack of manifestation of external deformities in field-sampled populations of adult freshwater turtles exposed to PCBs and other contaminants elsewhere (Bell et al. 2006, Davy \& Murphy 2009).

Operational sex ratio is a parameter of particular interest as an indicator of potential PCB impacts because PCB exposure has been suggested as a feminizing agent in turtles (Bergeron et al. 1994). A higher proportion of female snapping turtles was observed in the reference river segment in 2007, and a higher proportion of female painted turtles was observed in the reference river segment in 2007 and in 2006/2007 combined, patterns in contrast to expectations of $\mathrm{PCB}$-exposure as a feminizing agent in turtle populations. An alternate explanation relates to nest site choice and temperature-dependent sex determination because higher incubation temperatures generally yield increasing fractions of females in both painted (Schwanz \& Janzen 2008) and snapping turtles (Rhen \& Lang 1994). However, reduced forest cover and more extensive agricultural lands in the contaminated river segment (Table 1) would be expected to generate warmer incubation conditions for turtle nests (Schwanz \& Janzen 2008) and a higher, not lower, female fraction. The most likely explanation for the lower female fraction in the contaminated river segment is higher vulnerability to road mortality in female turtles. The contaminated river segment was far more urbanized, with an asso- 
ciated denser road network and heavier traffic (Table 1). Female turtles are killed disproportionately on roads because they undertake annual nesting migrations that males do not, resulting in malebiased sex ratios in more urbanized areas (Steen \& Gibbs 2004, Steen et al. 2006), a pattern we observed in this study.

In conclusion, this assessment of population parameters of aquatic turtles across a gradient of PCB contamination in the upper Hudson River, an environmental issue of nation-wide significance (Baker et al. 2006), failed to identify any contaminant-induced alteration of multiple, population-level endpoints in wild turtles. Turtles are late-maturing, long-lived, and largely sedentary higher-order predators, attributes that may make them useful meters of bioaccumulation of contaminants (Bishop et al. 1998) but poor indicators of contaminant effects on populations. This is because changes in the demographic parameters perhaps most sensitive to contaminantassociated effects, such as clutch size, egg survival, and hatchling survival (e.g. Salice et al. 2014), are also those to which population growth in turtles is least sensitive (Congdon et al. 1993, 1994). The lack of spatial trends we observed in population parameters of aquatic turtles associated with a strong gradient of PCB contamination contrasts with predictions of likely occurrence of adverse demographic impacts derived from population projection modeling (Salice et al. 2014), dose-response studies (Holliday et al. 2009), and tissue residue analyses (NOAA 2013). More field assessments in situ with well designed studies of clearly defined population-level endpoints will be needed to understand levels of PCB exposure that generate substantive adverse effects on wild populations of aquatic turtles.

Acknowledgements. Fieldwork was conducted by Alex Krofta, Thomas Bullock, Casey Tomkins, David Muska, and Joseph Willite. Viorel Popescu assisted with selected analyses. Project funding was provided by the General Electric Company. This work was conducted under New York State Department of Environmental Conservation License to Collect and Possess no. 898 and State University of New York College of Environmental Science and Forestry Institutional Animal Care and Use Committee Protocol 120301.

\section{LITERATURE CITED}

Akçakaya HR, Stark JD, Bridges TS (2008) Demographic toxicity: methods in ecological risk assessment. Oxford University Press, New York, NY

Baker JE, Bohlen WF, Bopp RF, Brownawell B and others (2006) PCBs in the upper and tidal freshwater Hudson River estuary: the science behind the dredging contro- versy. In: Levinton JS, Waldman JR (eds) The Hudson River Estuary. Cambridge University Press, New York, NY, p 349-367

Bell B, Spotila JR, Congdon J (2006) High incidence of deformity in aquatic turtles in the John Heinz National Wildlife Refuge. Environ Pollut 142:457-465

*Bergeron JM, Crews D, McLachlan JA (1994) PCBs as environmental estrogens: turtle sex determination as a biomarker of environmental contamination. Environ Health Perspect 102:780-781

* Bishop CA, Ng P, Pettit KE, Kennedy SW, Stegeman JJ, Norstrom RJ, Brooks RJ (1998) Environmental contamination and developmental abnormalities in eggs and hatchlings of the common snapping turtle (Chelydra serpentina serpentina) from the Great Lakes-St Lawrence River Basin (1989-1991). Environ Pollut 101:143-156

Bjornstad ON (2016) Version 11-7 Package 'ncf': spatial nonparametric covariance functions. http://cran.r-project.org/ web/packages/ncf/

Boarman WI, Goodlett T, Goodlett G, Hamilton P (1998) Review of radio transmitter attachment techniques for turtle research and recommendations for improvement. Herpetol Rev 29:26-33

Bowne DR, Bowers MA, Hines JE (2006) Connectivity in an agricultural landscape as reflected by inter-pond movements of a freshwater turtle. Conserv Biol 20:780-791

Brown GP, Bishop, CA, Brooks, RJ (1994) Growth rate, reproductive output, and temperature selection of snapping turtles in habitats of different productivities. J Herpetol 28:405-410

Burnham KP, Anderson DR (2002) Model selection and multimodel inference: a practical information-theoretic approach, $2^{\text {nd }}$ edn. Springer Science, New York, NY

Congdon JD, Dunham AE, van Loben Sels RC (1993) Delayed sexual maturity and demographies of Blanding's turtles (Emydoidea blandingii): implications for conservation and management of long-lived organisms. Conserv Biol 7:826-833

Congdon JD, Dunham AE, van Loben Sels RC (1994) Demographics of common snapping turtles (Chelydra serpentina): implications for conservation and management of long-lived organisms. Am Zool 34:397-408

*Davy CM, Murphy RW (2009) Explaining patterns of deformity in freshwater turtles using MacCulloch's hypothesis. Can J Zool 87:433-439

* DeCatanzaro R, Chow-Fraser P (2010) Relationship of road density and marsh condition to turtle assemblage characteristics in the Laurentian Great Lakes. J Gt Lakes Res 36:357-365

*Deem SL, Norton TM, Mitchell M, Segars A and others (2009) Comparison of blood values in foraging, nesting, and stranded loggerhead turtles (Caretta caretta) along the coast of Georgia, USA. J Wildl Dis 45:41-56

Eisenreich KM, Kelly SM, Rowe CL (2009) Latent mortality of juvenile snapping turtles from the upper Hudson River, New York, exposed maternally and via the diet to polychlorinated biphenyls (PCBs). Environ Sci Technol 43:6052-6057

Ernst CH, Lovich JE, Barbour RW (1994) Turtles of the United States and Canada. Smithsonian Institution Press, Washington, DC

Field A (2009) Discovering statistics using SPSS ( ${ }^{\text {rd }}$ edn). Sage, Los Angeles, CA

Galbraith DA, Chandler MW, Brooks RJ (1987) The fine structure of home ranges of male Chelydra serpentina: 
Are snapping turtles territorial? Can J Zool 65:2623-2629

Galbraith DA, Bishop CA, Brooks RJ, Simser WL, Lampman KP (1988) Factors affecting the density of populations of common snapping turtles (Chelydra serpentina). Can J Zool 66:1233-1240

Gardner TA, Barlow J, Peres CA (2007) Paradox, presumption and pitfalls in conservation biology: the importance of habitat change for amphibians and reptiles. Biol Conserv 138:166-179

Gibbs JP, Breisch AR, Ducey PK, Johnson G, Behler J, Bothner R (2007) The amphibians and reptiles of New York State: identification, natural history, and conservation. Oxford University Press, New York, NY

Hargrove WW, Pickering J (1992) Pseudoreplication: a sine qua non for regional ecology. Landsc Ecol 6:251-258

Hastie TJ, Tibshirani J (1990) Generalized additive models. Monographs on statistics and applied probability 43. Chapman \& Hall, London

Holliday DK, Holliday CM (2012) The effects of the organopollutant PCB 126 on bone density in juvenile diamondback terrapins (Malaclemys terrapin). Aquat Toxicol 109: 228-233

Holliday DK, Elskus AA, Roosenburg WM (2009) Impacts of multiple stressors on growth and metabolic rate of Malaclemys terrapin. Environ Toxicol Chem 28:338-345

Homer C, Dewitz J, Fry J, Coan M and others (2007) Completion of the 2001 National Land Cover Database for the conterminous United States. Photogramm Eng Remote Sensing 73:337-341

Hudson River Natural Resource Trustees (2005) Data report for the collection of eggs from the common snapping turtle (Chelydra serpentina serpentina) from the Hudson River, New York. Hudson River Natural Resource Damage Assessment Public Release Version March 30. US Department of Commerce, Silver Spring, MD

Hurlbert SH (1984) Pseudoreplication and the design of ecological field experiments. Ecol Monogr 54:187-211

Kelly SM, Eisenreich KM, Baker JE, Rowe CL (2008) Accumulation and maternal transfer of polychlorinated biphenyls in snapping turtles of the upper Hudson River, New York, USA. Environ Toxicol Chem 27:2565-2574

Kiviat E (1980) A Hudson River tidemarsh snapping turtle population. Trans Northeast Sect Wildl Soc 37:158-168

Knight AW, Gibbons JW (1968) Food of the painted turtle, Chrysemys picta, in a polluted river. Am Midl Nat 80: 558-562

MacCulloch RD, Secoy DM (1983) Movement in a river population of Chrysemys picta bellii in southern Saskatchewan. J Herpetol 17:283-285

MacKenzie DI (2012) PRESENCE user manual. Proteus Wildlife Research Consultants, Dunedin

MacKenzie DI, Nichols JD, Lachman GB, Droege S, Royle JA, Langtimm CA (2002) Estimating site occupancy rates when detection probabilities are less than one. Ecology 83:2248-2255

Mali I, Brown DJ, Ferrato JR, Forstner MR (2014) Sampling freshwater turtle populations using hoop nets: testing potential biases. Wildl Soc Bull 38:580-585

McCulloch CE, Shayle RS, Neuhaus JM (2008) Generalized, linear, and mixed models ( $2^{\text {nd }}$ edn). John Wiley \& Sons, New York, NY

NOAA (National Oceanic and Atmospheric Administration) (2013) PCB contamination of the Hudson River ecosystem. Compilation of contamination data through 2008. US Department of Commerce, Silver Spring, MD
Obbard ME, Brooks RJ (1981) A radio-telemetry and markrecapture study of activity in the common snapping turtle, Chelydra serpentina. Copeia 1981:630-637

* Patrick DA, Gibbs JP (2010) Population structure and movements of freshwater turtles across a road-density gradient. Landsc Ecol 25:791-801

Keam C, Ream R (1966) The influence of sampling methods on the estimation of population structure in painted turtles. Am Midl Nat 75:325-338

* Rhen T, Lang JW (1994) Temperature-dependent sex determination in the snapping turtle: manipulation of the embryonic sex steroid environment. Gen Comp Endocrinol 96:243-254

Rizkalla CE, Swihart RK (2006) Community structure and differential responses of aquatic turtles to agriculturally induced habitat fragmentation. Landsc Ecol 21:1361-1375

* Salice CJ, Rowe CL, Eisenreich KM (2014) Integrative demographic modeling reveals population level impacts of PCB toxicity to juvenile snapping turtles. Environ Pollut 184:154-160

* Schwanz LE, Janzen FJ (2008) Climate change and temperature-dependent sex determination: Can individual plasticity in nesting phenology prevent extreme sex ratios? Physiol Biochem Zool 81:826-834

Selcer KW (2006) Reptile ecotoxicology: studying effects of contaminants on populations. In: Gardner S, Oberdorster E (eds) Toxicology of reptiles. Taylor \& Francis Group, Boca Raton, FL, p 267-297

Sokal RR, Rohlf FJ (1995) Biometry: the principles and practice of statistics in biological research ( $3^{\text {rd }}$ edn). WH Freeman, New York, NY

Souza FL, Abe FS (2000) Feeding ecology, density, and biomass of the freshwater turtle, Phrynops geoffoanus, inhabiting a polluted urban river in south-eastern Brazil. J Zool (Lond) 252:437-446

* Steen DA, Gibbs JP (2004) Effects of roads on the structure of freshwater turtle populations. Conserv Biol 18:1143-1148

Steen DA, Aresco MJ, Beilke SG, Compton BW and others (2006) Relative vulnerability of female turtles to road mortality. Anim Conserv 9:269-273

US EPA (United States Environmental Protection Agency) (2000) Phase 2 Report - further site characterization and analysis. Vol 2E-revised baseline ecological risk assessment: Hudson River PCBs reassessment. US EPA Region II, New York, NY

Vispo C, Knab-Vispo C (2011) Ecology in the field of time: two centuries of interaction between agriculture and native species in Columbia County, New York. In: Henshaw RE (ed) Environmental history of the Hudson River: human uses that changed the ecology, ecology that changed human uses. SUNY Press, Albany, NY, p 165-182

*Weir SM, Suski JG, Salice CJ (2010) Ecological risk of anthropogenic pollutants to reptiles: evaluating assumptions of sensitivity and exposure. Environ Pollut 158:3596-3606

Wikelski M, Romero LM (2003) Body size performance and fitness in Galapagos marine iguanas. Integr Comp Biol 43:376-386

Wood S (2009) Version 00-2 Generalized additive mixed models using mgcv and lme4. http://cran.r-project.org/ web/packages/gamm4

Yu S, Halbrook RS, Sparling DW (2012) Accumulation of polychlorinated biphenyls (PCBs) and evaluation of hematological and immunological effects of PCB exposure on turtles. Bull Environ Contam Toxicol 88:823-827

Submitted: September 5, 2016; Accepted: March 31, 2017

Proofs received from author(s): April 28, 2017 